\title{
Effects of a $\beta$-Adrenergic Agonist (Clenbuterol) on Growth and Muscle Composition in Broiler Chicks Treated with or without Thyroxine
}

\author{
Yoshio IIAMano, Shu Yamazaki, Itaru Honma, \\ Shigeki KoBayashi and Yoshiaki Terashima \\ Faculty of Animal Sciences, Kitasato University, \\ Towada-shi 034
}

(Received December 2, 1994)

\begin{abstract}
The effects of a $\beta$-adrenergic agonist, clenbuterol (CL), on growth and muscle composition were examined in broiler chicks treated with or without thyroxine $\left(T_{4}\right)$. Fourteen day-old chicks were divided into 6 groups of 6 birds each and fed experimental diets incorporat-ing $\mathrm{T}_{4}(0$ or $1.2 \mathrm{ppm})$ and $\mathrm{CL}(0,1$ or $2 \mathrm{ppm})$ for 12 days. CL treatments decreased $(\mathrm{P}<0.05)$ body weight gain in regard to $T_{4}$ treatment, but did not affect feed intake or feed efficiency. Dietary $\mathrm{CL}$ and $\mathrm{T}_{4}$ increased $(\mathrm{P}<0.01)$ protein content in breast muscles. A significant interaction between $T_{4}$ and $C L$ treatments was detected $(P<0.05)$ in the fat content and protein : DNA ratio in the breast muscles. The CL treatment decreased $(P<0.05)$ fat content in $T_{4}$-untreated chicks but not in $\mathrm{T}_{4}$-treated birds. Dietary $\mathrm{CL}$ in increased $(\mathrm{P}<0.05)$ the protein : DNA ratio dosedependently in the chicks untreated with $T_{4}$. When the birds were treated with $T_{4}$, this ratio increased $(\mathrm{P}<0.05)$ and reached a plateau at a lower dose $(1 \mathrm{ppm})$ of CL. CL treatments increased $(\mathrm{P}<0.01)$ RNA : DNA ratio in regard to $\mathrm{T}_{4}$ treatment. These results suggest that $\mathrm{CL}$-induced muscle hypertrophy in broiler chicks involves thyroid status.
\end{abstract}

Anim. Sci. Technol. (Jpn.) 66 (7) : 599-604, 1995

Key words : $\beta$-adrenergic agonist, clenbuterol, thyroxine, muscle protein metabolism, broiler chick

Recent studies have demonstrated that die$\operatorname{tary} \beta$-adrenergic agonists $(\beta-A G)$ increase protein deposition and decrease fat deposition in

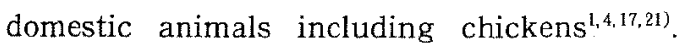
Many observations have indicated that muscle hypertrophy induced by $\beta-A G$ is due mainly to a reduction in protein breakdown rate ${ }^{11,14,23)}$.

The growth-promoting effects of $\beta-A G$ do not last over a long-term treatment, and are negated by a prolonged treatment or elevated dose levels of $\beta-A G^{2,4)}$. A decrease in the chronic effects of $\beta-A G$ on muscle growth results in part from a reduction in $\beta$-adrenergic receptor density on muscle cells by $\beta$-adrenergic stimulation ${ }^{9}$, though factors regulating $\beta$-adrenergic receptor density are not well known. If the depression of $\beta$-adrenergic receptor density, down-regulation, on skeletal muscle cells in animals treated with $\beta-A G$ can be prevented, $\beta-A G$ may in part enhance muscle growth in animals receiving prolonged treatment with $\beta-A G$.

The regulation of $\beta$-adrenergic receptor density or a $\beta$-adrenergic receptor-adenylate cyclase system is associated with thyroid hormones such as thyroxine $\left(\mathrm{T}_{4}\right)$ and triiodothy- 
Hamano, Yamazaki, Honma, Kobayashi and Terashima

ronine ${ }^{3,13,20)}$. $\beta$-adrenergic responsiveness to $\beta-A G$ in skeletal muscle may increase or decrease according to thyroid status. However, whether $\beta-A G$ and thyroid states possess an interrelationship for muscle growth or composition is still obscure.

The objective of the present study, therefore, was to determine the effects of a $\beta-A G$, clenbuterol (CL), on muscle growth in broiler chicks treated with or without thyroxine.

\section{Materials and Methods}

Day-old male broiler chicks of a Chunky strain were housed in battery brooders, and provided with a commercial starter diet until 14 days of age. Thirty-six chicks were chosen to have similar body weight, and divided into 6 dietary groups. The birds were individually housed in wire cages in a room it $24 \mathrm{~h} / \mathrm{d}$ and maintained at a temperature of $25^{\circ} \mathrm{C}$.

The chicks in each group were provided with experimental diets incorporating L-thyroxine sodium salt ( 0 or $1.2 \mathrm{ppm}$, Sigma, St. Louis. MO, USA) and clenbuterol (0,1 or 2 ppm, Sigma, St. Louis. MO, USA) in the basal diet (Table 1). Diets and water were given ad libitum over 12 days. Chicks were weighed at 2 day intervals, and feed intake was measured daily. At 26 days of age, the birds were killed, and the left side of their breast muscles (Musculus Pectoralis superficialis) and abdominal fat pads were removed and weighed. The breast muscles were stored at $-20^{\circ} \mathrm{C}$ until chemical analysis.

Breast muscles were used for the determination of protein, fat, DNA and RNA content. Protein content in breast muscles was determined by the biuret method of Gornall et $a l^{8}{ }^{8}$, after the breast muscles were homogenized in 3 $\mathrm{M} \mathrm{NaOH}$. Bovine serum albumin was used as a standard for protein analysis. Fat in the breast muscles was extracted by the FOLCH method $^{7}$, and determined by gravimetry. DNA and RNA from breast muscles were extracted by the method of SHIBKo et al. ${ }^{18)}$. DNA
Table 1. Composition of basal diet $(\%)$

\begin{tabular}{lc}
\hline Ingredients & \\
Isolated soybean protein ${ }^{1}$ & 16.5 \\
Ground yellow corn & 78.5 \\
Vitamin and mineral mixture ${ }^{2)}$ & 3.39 \\
DL-methionine & 0.26 \\
L-lysine HCl & 0.16 \\
Glycine & 0.20 \\
L-threonine & 0.05 \\
Cellulose & An \\
Analytical composition & 0.94 \\
Crude protein (\%) & \\
ME $^{4)}$ (kcal/kg) & 21.3 \\
\end{tabular}

1) Fujipro-R, Fujiseiyu Co., Ltd., Osaka, Japan.

2) Vitamin and mineral mixture: provided per $\mathrm{kg}$ diet. $10,000 \mathrm{IU}$ vitamin $A: 2,000$ ICU vitamin $D_{3}$; $5.0 \mathrm{mg} \alpha$-tocopherol acetate ; $2.5 \mathrm{mg}$ vitamin $\mathrm{K}_{3} ; 1.51$ mg cyanocobalamin ; $7.7 \mathrm{mg}$ riboflavin ; $1.5 \mathrm{mg}$ thiamin nitrate; $5.28 \mathrm{mg}$ calcium panthothenate; $10.4 \mathrm{mg}$ folic acid; $18.2 \mathrm{mg}$ nicotinic acid: $1.5 \mathrm{mg}$ pyridoxine hydrochloride; $0.11 \mathrm{mg}$ biotin ; $880 \mathrm{mg}$ choline chloride ; $7.2 \mathrm{~g} \mathrm{CaCO}_{3} ; 17.8 \mathrm{~g} \mathrm{CaHPO}_{4} \cdot 2 \mathrm{H}_{2} \mathrm{O}$; $2.9 \mathrm{~g} \mathrm{NaCl} ; 5.0 \mathrm{mg} \quad \mathrm{CuSO}_{4} \cdot 5 \mathrm{H}_{2} \mathrm{O} ; 0.13 \mathrm{~g} \quad \mathrm{MnSO}_{4} \cdot 6$ $\mathrm{H}_{2} \mathrm{O} ; 0.13 \mathrm{~g} \mathrm{ZnSO} \cdot 7 \mathrm{H}_{2} \mathrm{O} ; 50 \mathrm{mg} \quad \mathrm{FeSO}_{4} \cdot 7 \mathrm{H}_{2} \mathrm{O}$ and $0.6 \mathrm{mg} \mathrm{KI}$.

3) Cellulose Powder D (40-100 mesh), Toyo Roshi Co., Ltd., Tokyo, Japan.

4) Calculated value.

was quantified by the diphenylamine method ${ }^{16)}$ using calf thymus DNA as a standard. RNA was determined by the orcinol reaction ${ }^{10)}$ using purified yeast RNA as a standard.

All data were analyzed by two-way analysis of variance according to a $2 \times 3$ factorial sheme. When significant interactions between $\mathrm{T}_{4}$ and $\mathrm{CL}$ were detected, the significant differences among CL levels in each $\mathrm{T}_{4}$-treated group were tested by Tukey's multiple range test.

\section{Results}

The effects of CL on body weight gain. feed intake and feed efficiency in chicks treated with or without $T_{4}$ are shown in Table 2. CL treatment decreased $(P<0.05)$ body weight gain in regard to $T_{4}$ treatment, but did not affect feed intake or feed efficiency. 


\section{Clenbuterol and Thyroxine in Chicks}

The effects of CL on the weight of abdominal fat and breast muscle, and muscle composition, in chicks treated with or without $T_{4}$ are shown in Table 3. CL treatment did not affect abdominal fat weight, though $T_{4}$ treatment decreased $(\mathrm{P}<0.01)$ this parameter. No significant influence of either the $\mathrm{T}_{4}$ or $\mathrm{CL}$ treatment was detected in breast muscle weight.

Dietary $\mathrm{T}_{4}$ and $\mathrm{CL}$ distinctly increased $(\mathrm{P}<$ $0.01)$ protein content in breast muscles. The increased protein content in CL-treated groups was further reinforced by $T_{4}$ treatment. A sig- nificant interaction between $\mathrm{T}_{4}$ and $\mathrm{CL}$ was observed in the fat content of breast muscles ( $P$ $<0.05)$. $\mathrm{CL}$ treatment $(2 \mathrm{ppm})$ decreased $(\mathrm{P}<$ 0.05 ) fat content in breast muscles when birds were untreated with $\mathrm{T}_{4}$. In $\mathrm{T}_{4}$-treated groups, $\mathrm{CL}$ treatment did not affect fat content in breast muscles. DNA content in breast muscles evidently decreased $(\mathrm{P}<0.01)$ due to $\mathrm{CL}$ treatment in regard to $\mathrm{T}_{4}$ treatment.

A significant interaction $(P<0.05)$ between $T_{4}$ and $\mathrm{CL}$ was observed in the protein: DNA ratio. Dietary CL markedly increased the pro-

Table 2. The effects of clenbuterol (CL) on body weight (BW) gain, feed intake and feed efficiency in broiler chicks treated with or without thy roxine $\left(\mathrm{T}_{4}\right)^{1)}$

\begin{tabular}{|c|c|c|c|c|c|c|c|c|c|}
\hline \multirow{2}{*}{$\begin{array}{l}\mathrm{T}_{4}(\mathrm{ppm}) \\
\mathrm{CL}(\mathrm{ppm})\end{array}$} & \multicolumn{3}{|c|}{0} & \multicolumn{3}{|c|}{1.2} & \multicolumn{3}{|c|}{ Analysis of Variance ${ }^{2)}$} \\
\hline & 0 & 1 & 2 & 0 & 1 & 2 & $\mathrm{~T}_{4}$ & CL & $\mathrm{T}_{4} \times \mathrm{CL}$ \\
\hline Final BW (g) & $792 \pm 34$ & $729 \pm 66$ & $753 \pm 21$ & $810 \pm 29$ & $777 \pm 38$ & $721 \pm 31$ & & & \\
\hline $\begin{array}{l}\mathrm{BW} \text { gain } \\
\text { (g/12 days) }\end{array}$ & $489 \pm 29$ & $421 \pm 60$ & $445 \pm 28$ & $564 \pm 27$ & $478 \pm 27$ & $407 \pm 28$ & NS & $*$ & NS \\
\hline $\begin{array}{l}\text { Feed intake } \\
\text { (g/12 days) }\end{array}$ & $698 \pm 42$ & $616 \pm 49$ & $658 \pm 31$ & $740 \pm 45$ & $677 \pm 31$ & $617 \pm 30$ & NS & NS & NS \\
\hline Feed efficiency ${ }^{3)}$ & $0.70 \pm 0.03$ & $0.67 \pm 0.05$ & $0.67 \pm 0.02$ & $0.71 \pm 0.02$ & $0.70 \pm 0.01$ & $0.66 \pm 0.02$ & NS & NS & NS \\
\hline
\end{tabular}

1) Values represent means for 6 chicks with $\mathrm{SE}$.

2) * : $\mathrm{P}<0.05$, NS : Not significant.

3) BW gain/feed intake $(\mathrm{g} / \mathrm{g})$.

Table 3. The effects of clenbuterol (CL) on the weights of abdominal fat and breast muscle, and breast muscle composition in broiler chicks treated with or without thyroxine $\left(\mathrm{T}_{4}\right)^{1)}$

\begin{tabular}{|c|c|c|c|c|c|c|c|c|c|}
\hline \multirow{2}{*}{$\begin{array}{l}\mathrm{T}_{4}(\mathrm{ppm}) \\
\mathrm{CL}(\mathrm{ppm})\end{array}$} & \multicolumn{3}{|c|}{0} & \multicolumn{3}{|c|}{1.2} & \multicolumn{3}{|c|}{ Analysis of Variance ${ }^{2)}$} \\
\hline & 0 & 1 & 2 & 0 & 1 & 2 & $T_{4}$ & $\mathrm{CL}$ & $\mathrm{T}_{4} \times \mathrm{CL}$ \\
\hline $\begin{array}{l}\text { Abdominal fat } \\
\text { weight } \\
\text { (g/100g BW) }\end{array}$ & $1.09 \pm 0.09$ & $0.84 \pm 0.09$ & $0.88 \pm 0.08$ & $0.61 \pm 0.12$ & $0.61 \pm 0.09$ & $0.51 \pm 0.06$ & $* *$ & NS & NS \\
\hline $\begin{array}{l}\text { Breast muscle } \\
\text { weight } \\
(\mathrm{g} / 100 \mathrm{~g} \mathrm{BW})\end{array}$ & 4. $96 \pm 0.32$ & $4.77 \pm 0.54$ & $5.36 \pm 0.18$ & $4.82 \pm 0.32$ & $5.16 \pm 0.32$ & $5.08 \pm 0.26$ & NS & NS & NS \\
\hline Protein (mg/g) & $210 \pm 4$ & $221 \pm 3$ & $230 \pm 4$ & $229 \pm 6$ & $239 \pm 8$ & $244 \pm 3$ & $* *$ & $* *$ & NS \\
\hline Fat $(\%)$ & $1.53 \pm 0.31^{\mathrm{a}}$ & 1. $16 \pm 0.21^{\mathrm{ab}}$ & $0.84 \pm 0.01^{\mathrm{b}}$ & $0.85 \pm 0.15$ & $0.87 \pm 0.09$ & $1.04 \pm 0.09$ & $*$ & NS & $*$ \\
\hline DNA (mg/g) & $0.32 \pm 0.02$ & $0.25 \pm 0.01$ & $0.22 \pm 0.01$ & $0.33 \pm 0.03$ & $0.23 \pm 0.01$ & $0.25 \pm 0.01$ & NS & $* *$ & NS \\
\hline $\begin{array}{l}\text { Protein : DNA } \\
\quad \text { ratio (mg/mg) }\end{array}$ & $688 \pm 27^{a}$ & $889 \pm 55^{b}$ & $1048 \pm 46^{c}$ & $616 \pm 30^{a}$ & $1068 \pm 78^{b}$ & $1002 \pm 78^{b}$ & NS & $* *$ & $*$ \\
\hline $\begin{array}{l}\text { RNA : DNA } \\
\text { ratio }(\mathrm{mg} / \mathrm{mg})\end{array}$ & $4.62 \pm 0.21$ & $5.78 \pm 0.32$ & $5.18 \pm 0.46$ & $2.72 \pm 0.24$ & $5.59 \pm 0.32$ & $4.44 \pm 0.49$ & $* *$ & ** & NS \\
\hline
\end{tabular}

1) Values represent means for 6 chicks with SE.

2) * : $\mathrm{P}<0.05, * *: \mathrm{P}<0.01, \mathrm{NS}:$ Not significant.

$a_{b} b, c:$ Significant difference among $C L$ levels in each $T_{4}$ treated group $(P<0.05)$. 
tein: DNA ratio regardless of $T_{4}$ treatment. The magnitude of difference in this ratio between the CL-treated (1 ppm) and untreated chicks was greater in the $\mathrm{T}_{4}$-treated group than in the $\mathrm{T}_{4}$-untreated group. CL treatments increased $(\mathrm{P}<0.01)$ the RNA : DNA ratio in the breast muscles in regard to $T_{4}$ treatment.

\section{Discussion}

In growing animals, $\beta-A G$ brings about an increase in muscle protein deposition and muscle mass ${ }^{4,5,11,12,14,17,23)}$. The present study also showed that an increase in protein deposition in the breast muscle is induced by $\mathrm{CL}$ treatment. Protein deposition occurs when the prorein synthesis rate excels the protein degradation rate $^{19)}$. Therefore, a $\beta$-AG-induced protein deposition will result from an increased protein synthesis rate, a decreased protein degradation rate or both. In the present study, dietary CL enhanced the RNA: DNA ratio in the breast muscle. The RNA : DNA ratio in a tissue is closely related to the protein synthesis rate, and can be estimated as the protein synthetic capacity ${ }^{19}$.

Muramatsu et al ${ }^{12)}$ observed that CL treatment $(0.25 \mathrm{ppm})$ for 3 weeks does not affect the protein synthesis rate in the breast muscle of White Leghorn chicks. Many observations have also suggested that $\beta$-AG mainly decreases proteolysis in skeletal muscle ${ }^{11,15,22,23)}$. On the other hand, EADARA et al. ${ }^{5)}$ indicated that a $\beta$-adrenergic agonist, cimaterol, enhances the protein synthesis rate and reduces the potein breakdown rate in rats fed a highcarbohydrate diet based on glucose. Although muscle protein turnover rates were not determined in the present study, CL treatment possibly enhanced protein deposition in breast muscles by an increase in protein synthesis and a decrease in protein breakdown.

CL treatments increased the protein : DNA ratio, which can be interpreted as an index of muscle cell size ${ }^{19}$. The $\mathrm{CL}$ treatments increased muscle cell size with the increased pro- tein deposition in the breast muscles. The magnitude of difference in this ratio between CL-treated (1 ppm) and -untreated chicks was greater in the $T_{4}$-treated group than in the $T_{4}{ }^{-}$ untreated group. This result seems related to $\beta$-adrenergic responsiveness. $\mathrm{C}_{\mathrm{HU}}$ et $a l^{3)}$ showed that trijodothy ronine supplementation in vitro increased $\beta$-adrenergic receptor density on the skeletal muscle cells of rats treated with propylthiouracil. Thyroid status, such as hyper- or hypothyroidism, possesses an interrelationship with the regulation of the $\beta$-adrenergic receptor number or the $\beta$-adrenergic response in several tissues including the skeletal muscle ${ }^{13,20)}$. Dietary $T_{4}$ presumably improved CL-induced protein deposition by inhibiting down-regulation or adenylate cyclase activity in this experiment.

Thyroid hormones enhance muscle protein deposition resulting from an increase in the muscle protein turnover rate in growing animals ${ }^{6)} . \quad T_{4}$ treatment of broiler chickens increases the muscle protein synthesis rate, and to a smaller extent, simultaneously, the breakdown rate ${ }^{21)}$. However, the apparent influence of $T_{4}$ treatment on muscle growth was not observed for breast muscles, although the fat deposition estimated from abdominal fat weight significantly decreased via treatment with $T_{4}$ in the present study.

The action of $\beta-A G$ on muscle growth probably has at least an indirect effect on thyroid hormones through the $\beta$-adrenergic receptor function, though it is unknown if $\beta-A G$ affects the circulatory level of the thyroid hormone. If $\beta-A G$ directly (in part) affects muscle growth, down-regulation caused by a prolonged treatment with $\beta-A G$ will reflect on the response to $\beta-\mathrm{AG}$ on muscle cell. KIM et al..$^{93}$ observed that the reduction in $\beta$-adrenergic receptor density on skeletal muscle cells is caused by the treatment of rats with cimaterol for 3 days. $T_{4}$ may possibly induce the maximum effects of $\beta-A G$ on muscle growth. From these results, the present study suggests 
that CL induced muscle hypertrophy was involved in thyroid status.

\section{References}

1) Baker, P.K., R.H. DAlRymple, D.L. Ingle and C. A. RICKS, Use of $\beta$-adrenergic agonist to alter muscle and fat deposition in lambs. J. Anim. Sci., 59 : 1256-1261. 1984.

2) Buyse, J., E. Decuypere, G. Huyghebaert and M. Herremans, The effect of clenbuterol supplementation on growth performance and on plasma hormone and metabolite levels of broilers. Poult. Sci., 70 : 993-1002. 1991.

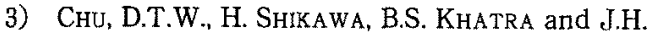
ExTon, Effects of altered thyroid status on $\beta-$ adrenergic actions on skeletal muscle glycogen metabolism. J. Biol. Chem., 260 : 999410000. 1985.

4) DAlRymple, R.H., P.K. BAKer, P.E. Gingher, D.L. INGLE, J.M. PENSACK and C.A. RiCKS, A repartitioning agent to improve performance and carcass composition of broilers. Poult. Sci., 63 : 2376-2383. 1984.

5) Eadara, J.K., R.H. Dalkymple, R.L. Delay, C.A. RicKs and D.R. Romsos, Effects of cimaterol, a $\beta$-adrenergic agonist, on protein metabolism in rats. Metabolism., $38: 883-890.1989$.

6) Evers, B., Hormonal effects on protein turnover. in Protein Metabolism in Farm Animals (Bock, H.-D., B.O. Eggum, A.G. Low, O. Simon and T. ZEBRowSKA, eds.) 367-403. Oxford University Press. Berlin. 1989.

7) Folch, J., M. Less and G.H. Sloan-Stanley, A simple method for the isolation and purification of total lipids from animal tissues. J. Biol. Chem., $226:$ 497-509. 1957.

8) Gornall, A.G., C.J. Bordawill and M.M. David, Determination serum proteins by means of biuret reaction. J. Biol. Chem., $177: 751-766$. 1949.

9) KIM, Y.S., R.D. SAINZ, R.J. SUMMERS and P. MOLENAAR, Cimaterol reduces $\beta$-adrenergic re. ceptor density in rat skeletal muscles. J. Anim. Sci., 70 : 115-122. 1992.

10) Lin, R.I.S. and O.A. SchJEIDE, Micro estimation of RNA by the cupric ion catalyzed orcinol reaction. Anal. Biochem., 27 : 473-483, 1969.

11) Morgan, J.B., S.J. Jones and C.R. Calkins, Muscle protein turnover and tenderness in broiler chickens fed cimaterol. J. Anim. Sci., 67 : 2646-2654. 1989.

12) Muramatsu, T., M. Kakita, Y. Aoyagi and J. OKumURA, Research note : $\beta$-adrenergic agonist effects on liver and breast muscle protein synthesis in female chicks. Poult. Sci., 70 : 1630-1632. 1991.

13) NunEz, J., Mechanism of action of thy roid hormone. in Hormones and Their Action, Part I (CoOKE, B.A., R.J.B. KING, and H.J. van del Molen, eds.). 61-80. Elsevier Science Publishers BV. 1988.

14) ReEds, P.J., S.M. HAY, P.M. DoRwood and R.M. PALMER, Stimulation of muscle growth by clenbuterol ; Lack of effect on muscle protein biosynthesis. Br. J. Nutr., 56 : 249-258. 1986.

15) Reeds, P.J. and H.J. Mersmann, Protein and energy requirements of animals treated with $\beta$-adrenergic agonists : a discussion. J. Anim. Sci., 69 : 1532-1550. 1991.

16) Richards, G.M., Modifications of diphenylamine reaction giving increased sensitivity and simplicity in the estimation of DNA. Anal. Biochem., $57: 369-376.1974$.

17) Ricks, C.A., R.H. Dalrymple, P.K. Baker and D. L. INGLE, Use of $\beta$-adrenergic agonist to alter fat and muscle deposition in steers. J. Anim. Sci., 59 : 1247-1255. 1984.

18) Shibko, S.P., P. Kiovistoinen, C.A. TRatnyek, A. R. Newhall and L. Friedmen, A method for sequential quantitative separation of protein, RNA, DNA, lipid and glycogen from a single rat liver homogenate from a subcellular fraction. Anal. Biochem., $19: 514-528.1967$.

19) Simon, O., Metabolism of proteins and amino acids, in Protein Metabolism in Farm Animals (Bock, H.-D., B.O. EgGuM, A.G. Low, O. SimoN and T. ZEBROWSKA, eds.). 273-366. Oxford University Press. Berlin. 1989.

20) Stiles, G.L., Drug and hormonal regulation of the beta-adrenergic receptor-adenylate cyclase system. in The Beta-Adrenergic Receptors (Perkins, J.P., eds.). 345-386. The Humana Press Inc. New Jersey. 1991.

21) Suthama, N., K. Hayashi, M. Toyomizu and Y. TOMITA, Interactions of exogenous thyroxine and dietary protein levels on growth and muscle protein metabolism in broiler chickens. Jpn. Poult. Sci., $28: 1-10.1991$.

22) WePpleman, R.M., Effects of gonadal steroids and adrenergic agonists on avian growth and feed efficiency. J. Exp. Zool. $232:$ 461-464. 1984.

23) William, P.E.V., L. Pagliani, G.M. Innes, K. Pennie, C.I. Harris and P. Garthweite, Effects of a $\beta$-agonist (clenbuterol) on grow th, carcass composition, protein and energy metabolism of veal calves. Br. J. Nutr., $57:$ 417-428. 1987. 


\title{
サイロキシンを投与したブロイラー雛の成長および骨格筋組成に 対する $\beta$-アゴニスト（クレンブテロール）の影響
}

\author{
濱野美夫 - 山㟝 周 - 本間 至 - 小林茂樹 - 寺島福秋 \\ 北里大学獣医畜産学部，十和田市 034
}

\begin{abstract}
サイロキシンを投与したブロイラー雊の成長および骨格笳組成に対する $\beta$-アゴニスト（クレンブテ ロール）の影響を検討した， 2 週龄の維を 6 羽ずつ 6 区に分け，各区の雏に基礎飼料へサイロキシン $(0$ または $1.2 \mathrm{ppm})$ ，さらにクレンブテロール(0，1 および $2 \mathrm{ppm})$ を添加した実験飼料を 12 日間給与し た。クレンブテロールはサイロキシン投与に関係なく, 增体量を減少 $(\mathrm{P}<0.05)$ させたが, 飼料摄取量 および飼料効率には影響を及隹さなかった。 クレンブテロールおよびサイロキシン投与は，浅胸筋の蛋 白質含量を有意 $(P<0.01)$ に增加させた. クレンブテロールとサイロキシンの有意 $(P<0.05)$ な交互作 用が，浅胸筋の全脂肪含量および蛋白質：DNA 比に認められた．クレンブテロールは，サイロキシン無 処理雛における全脂肪含量を有意 $(\mathrm{P}<0.05)$ に低下させたが, サイロキシン投与犨では, 影響を及ぼさ なかった，サイロキシン無処理区においては，クレンブテロール投与量の增加に伴って，蛋白質 : DNA

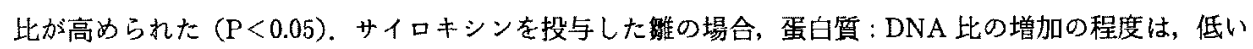
クレンブテロール投与区 (1 ppm)において，より高められた. RNA：DNA 比は，サイロキシン投与に 関係なくクレンブテロール投与によって増加 $(\mathrm{P}<0.01)$ した. これらの結果から, クレンブテロールが すたらした骨各筋蛋白質蓄積量および細胞容量の増加は, 甲状腺機能の状態上関係すると示唆された。
\end{abstract}

日畜会報, 66 (7): 599-604, 1995 